\title{
Petrology and Geochemical Properties of the Granitoid Complex of Chahar-Gonbad, Southeast Iran
}

\author{
Abdolhamid Ansari ${ }^{*}$, Seyed Jamal Sheikh Zakariaii ${ }^{\#}$, Sara Dargahi ${ }^{2 \dagger}$, Mohsen Arvin ${ }^{2 \ddagger}$ \\ ${ }^{1}$ Department of Geology, Science and Research Branch, Islamic Azad University, Tehran, Iran \\ ${ }^{2}$ Department of Geology, Shahid Bahonar University of Kerman, Kerman, Iran \\ Email:\#j.Sheikhzakria@gmail.com
}

How to cite this paper: Ansari, A., Zakariaii, S.J.S., Dargahi, S. and Arvin, M. (2017) Petrology and Geochemical Properties of the Granitoid Complex of Chahar-Gonbad, Southeast Iran. Open Journal of Geology, 7, 847-858.

https://doi.org/10.4236/ojg.2017.76058

Received: September 7, 2016

Accepted: June 27, 2017

Published: June 30, 2017

Copyright @ 2017 by authors and Scientific Research Publishing Inc. This work is licensed under the Creative Commons Attribution International License (CC BY 4.0).

http://creativecommons.org/licenses/by/4.0/

c) (i) Open Access

\begin{abstract}
The Chargonbad batholite is located in Sirjan and southeast of magmatic zone of Urumieh-Dokhtar. The main volume of this rocks consisted of Granodiorite and Monzogranite, but it's also consists of Quartzdiorite, Tonalite and Syenogranite. They have allotrimorphic granular texture with subordinate porphyritic texture. Their enclaves consist of: xenoliths enclaves, microgranular mafic enclaves (Diorite to Quartzdiorite in composition) and autolite enclaves (Tonalite, granodiorite and monzogranite in composition). The Chargonbad batholite rocks are also cut by different types of dykes which are mainly consisted of dykes and veins of pegmatic stage, microgranular dykes (andesit and andesit basaltic in composition) and microgranular dykes that are similar to mafic enclaves. Evidence shows that regional examples represent properties of granitoids type I. As well as, Granite of Granitoid body of this area has magnesium nature and shows the cordellarian granites features. Based on the tectonomagmatic environment determination diagrams, all samples from the Chahargonbad study area located in the arc island setting due to subduction and show the characteristic of active continental margin setting.
\end{abstract}

\section{Keywords}

Petrology and Geochemical Properties Granitoid Complex, Southeast Iran

\section{Introduction}

Chahar Gonbad granitoid mass is situated in geographic longitudes $\left(56^{\circ} 10^{\prime}\right.$ $\left.56^{\circ} 21^{\prime}\right)$ and latitudes $\left(29^{\circ} 34^{\prime}-29^{\circ} 34^{\prime}\right)$ at $80 \mathrm{~km}$ distant from northeast of Sirjan

${ }^{*}$ Ph.D Student.

\#Assistant professor.

$\dagger$ Assistant professor.

‡Professor. 
zone and $32 \mathrm{~km}$ at northwest of Belord county in Kerman province and with respect to structural-sedimentary divisions of Iran [1] and it is located at southeast of Uremia-Dokhtar magmatic belt [2]. Most of granitoids is composed of granitoid to granodiorite at southwest of Kerman and they are metaluminous and calc-alkaline [3]. The rocks which include this granitoid mass are Eocene volcanic-sedimentary complex that is the oldest rock unit in this zone and it is well visible at south and east of this region. Given the granitic rocks have only crossed Eocene rocks one can attribute these rocks at least to post-Eocene magmatism in terms of age where they have intrude and placed due to performance of Chahar Gonbad fault. Several dikes have crossed this plutonic mass where their array has also crossed Eocene volcanic-sedimentary complex as well. The studied rocks in Chahar Gonbad zone were divided into four groups of extrusive and intrusive igneous rocks, xenolith, and clastic igneous rocks. The extrusive igneous rocks are as follows: 1) andesite, 2) rhyolite, and 3) dolerite. Intrusive igneous rocks include i) diorite with quartz content, ii) tonalite, iii) granodiorite, and iv) granite (monzogranite and syenogranite). Rocks in xenolith groups and clastic igneous group of rocks comprise of tuffs. We will examine the evidences of magmatic evolution in granitoid rocks in this zone in the following. This study is intended to explore petrographic and geochemical evidences of magmatic evolution in granitoid rocks in Chahar Gonbad zone and determine tectonic environment of rocks in this zone.

\section{Geostrategic}

Tectonic factors in the westward and SW of Iran could be classified such 1) UDMC, 2) Sirjan-Sanadaj Region and 3) Zagros Fold-Thrust [4].

The UDMC includes Eocene-Quaternary plutonic and volcanic stones $4 \mathrm{~km}$ thicknesses and $50 \mathrm{~km}$ long [5]. But, the utmost of the magmatic action happened at Eocene which contains different of volcanic stones. However, Cretaceous parts were discernible in this region north too (Figure 1). The volcanic action was expelled in Upper Miocene and extended by Pliocene-Quaternary and identified by basaltic dacites and andesites as lava runs and heads and volcanic detritus flow. The emplacement age of these stones has not been delimited via geochronological period, however, according to stratigraphical investigations; the mentioned stones are fresher than Miocene. Apparently, the present volcanic action started in the late Miocene and extended by Pliocene. The UD volcanic stones have several, chemical, mechanical and petrological from acidic to primary and so creation conditions from continental to low marine depth. The acidic igneous masses were in sufficient associated via average till primary stones and frequently made because of continental shell melting [6].

Tafresh region is a section of the UDMC found in the center Iran. The UDMC is a portion of the Alpe-Himalayan orogenic belt and located within Arabian and Eurasian range in the same bias via Sirjan-Sanandaj changed region (Northwest, East south). The magmatic of the proposed belt is a debated issue, as some of the researchers [7] correlate it to the intracontinental cracks. Whereas other reserachers [8] [9] offer the subduction of the Neotethyan oceanic lithosphere 


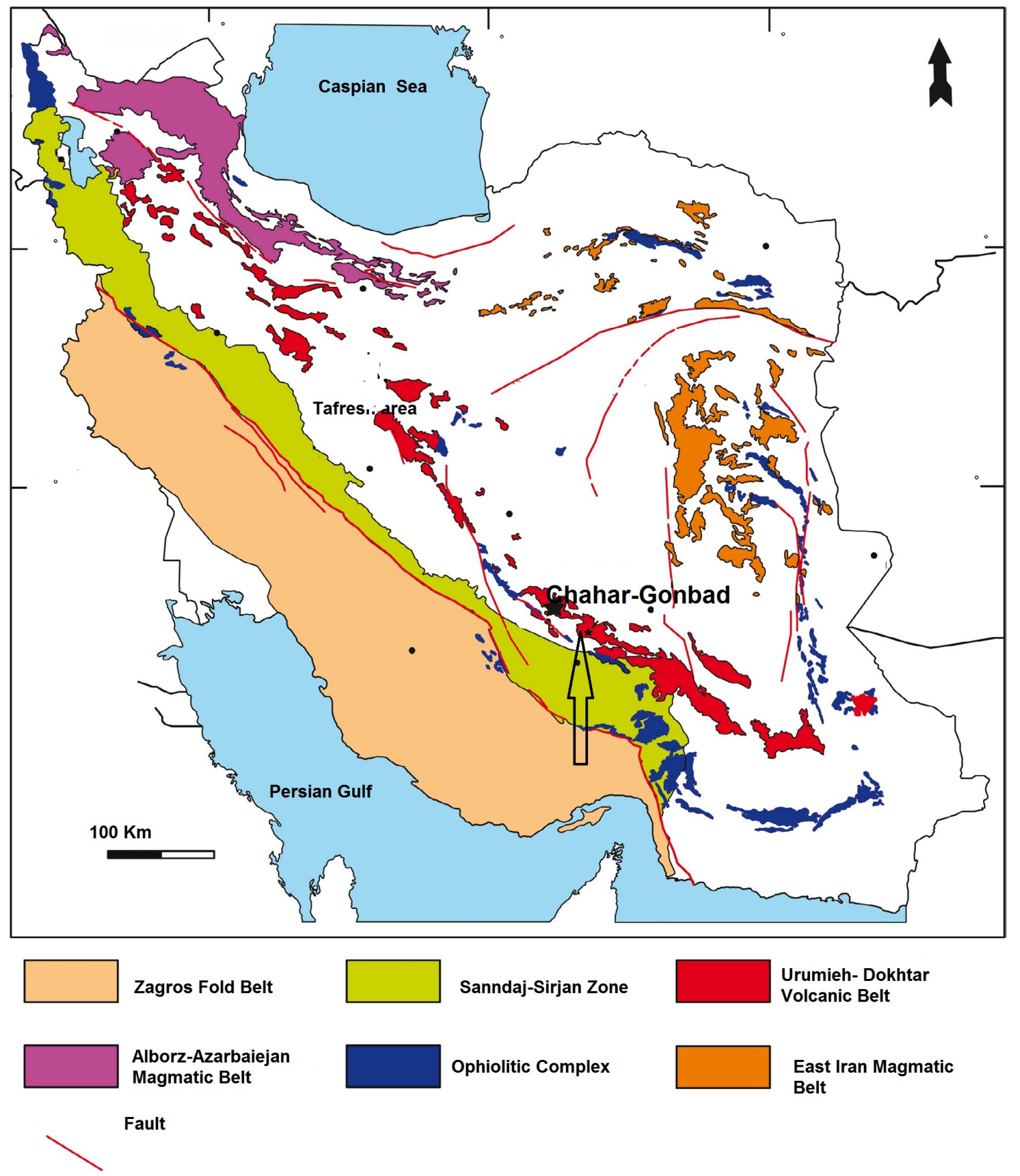

Figure 1. Schematic of Iran map, displaying the division of the main sedimentary and tectonic parts. The UrumiehDokhtar magmatic arc is of regularly Eocene-Miocene age, some of the other volcanic stones are older.

under the center Iran plate as the cause of the magmatic.

The principal purposes of the current research are to show geochemical aspects, as well as recognized area links of the Chahar-Gonbad complex, to characterize igneous magmatism, discover it's the main source and the tectonic situation in the Sirjan-Sanandej District and to cast light on the Rocky history and associated magnates in Iran. The information in the present work is essential for the recognition of the appearance of a subduction region in South-west of Iran over the Cenozoic. 


\section{Context of Geological}

The Chahar-Gonbad granitoid complex is located $80 \mathrm{~km}$ north east of Sirjan city, Kerman province, southeast of Iran, which lies between $29^{\circ} 34^{\prime} \mathrm{N}-29^{\circ} 42^{\prime} \mathrm{N}$ and between $56^{\circ} 10^{\prime} \mathrm{E}-56^{\circ} 21^{\prime} \mathrm{E}$ (Figure 1).

Chahar-Gonbad granitoids contain quartz diorite, Tonalite, synogranite, granodiorite and monzogranite. The granodiorites were extensive through the region and the largest interference in the region. They are white, gray to pinkish and commonly medium to coarse-grained stones and have a granular to porphyritic form presenting a plain Mineralogy: Plagioclase (35 - 45 percent mod.), K-feldspar (9 - 20 percent mod.), Quartez (21 - 40 percent mod.), Biotite (more than ten percent mod.) (Figure 2).

\section{Materials and Methods}

Approximately 100 examples of the granitoid stones gathered from various facies. To correctly characterize their chemical structures, 20 fresh specimens were taken for principal, track, and rare-earth-elements (REE) investigation. Principal and track factor wealth were discovered by inductively joined plasma atomic effusion and inductively joined plasma-mass spectrometries at the Karaj Standard labs in Iran. The scientific methods are explained in [10].

\section{Geochemical properties}

The $\mathrm{SiO}_{2}$ amount of cases changes between 53 by 76 wt percent (Table 1 ). Large share of cases make approximate linear to curvilinear biases of reducing $\mathrm{MnO}, \mathrm{TiO}_{2}, \mathrm{Al}_{2} \mathrm{O}_{3}, \mathrm{Fe}_{2} \mathrm{O}_{3}{ }^{*}, \mathrm{MgO}, \mathrm{P}_{2} \mathrm{O}_{5}$, and $\mathrm{CaO}$, and developing $\mathrm{Na}_{2} \mathrm{O}$ and $\mathrm{K}_{2} \mathrm{O}$ via growing $\mathrm{SiO}_{2}$ (Figure 3). The models of these in the $\mathrm{Al}_{2} \mathrm{O}_{3}, \mathrm{P}_{2} \mathrm{O}_{5}, \mathrm{CaO}, \mathrm{MgO}$, $\mathrm{FeO}, \mathrm{TiO}_{2}$ versus $\mathrm{SiO}_{2}$ figures show decreasing trend versus increased $\mathrm{SiO}_{2}$ plot. These models recommend that fractionation and crystallization of plagioclase, hornblende, a Ti-bearing state, and apatite should have performed functions in the stones.

Harker pictures of the principal factors show amazing biases recommending

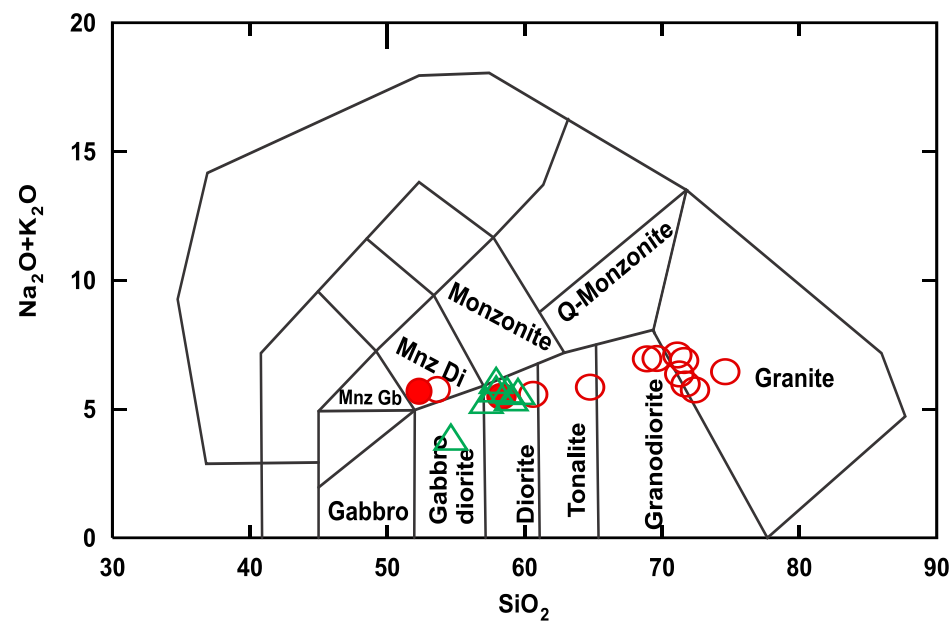

Figure 2. Total Akkali versus $\mathrm{SiO}_{2} \mathrm{f}$ for major factors of the ChaharGonbad Granitoid complex. 


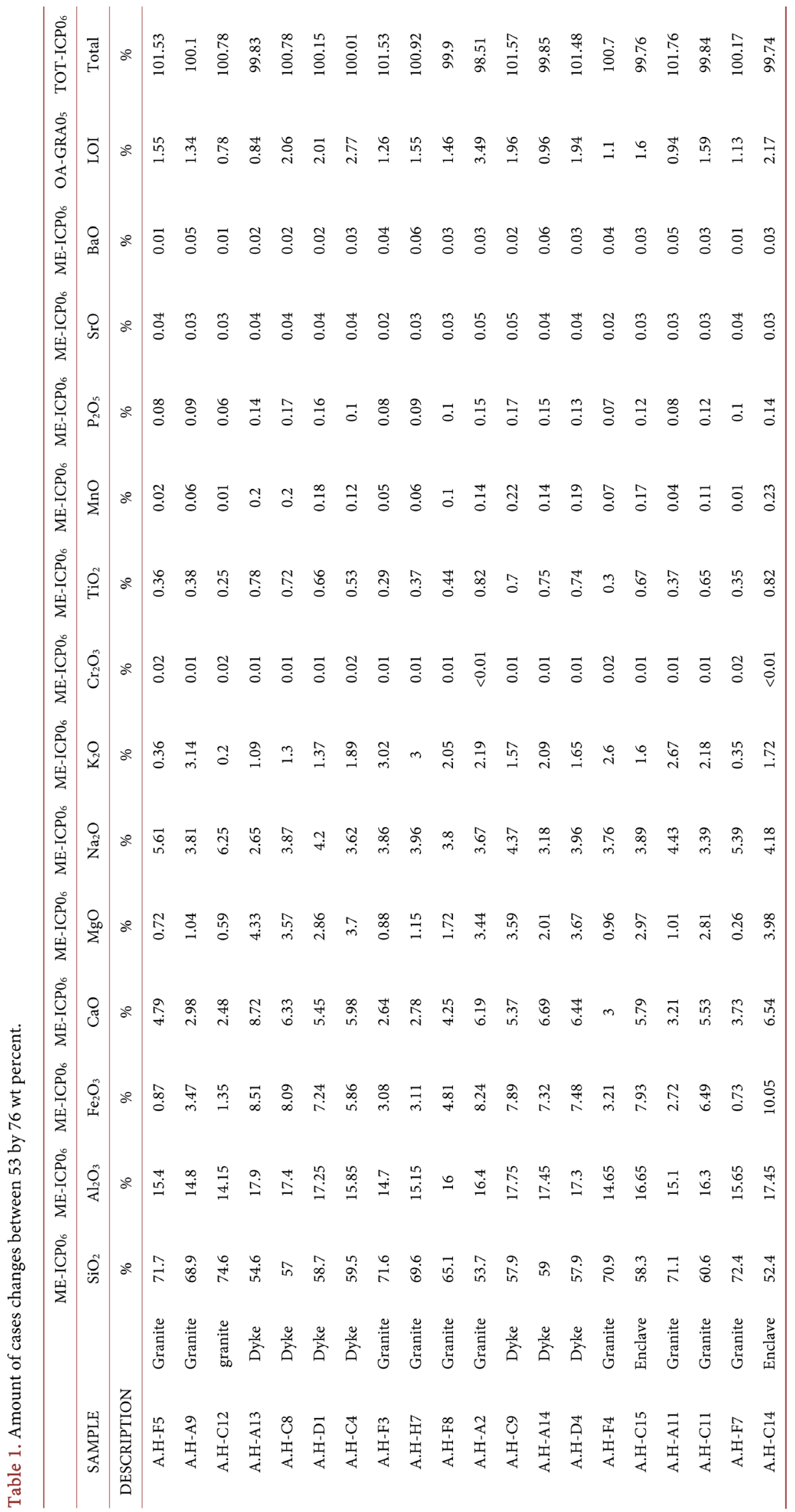




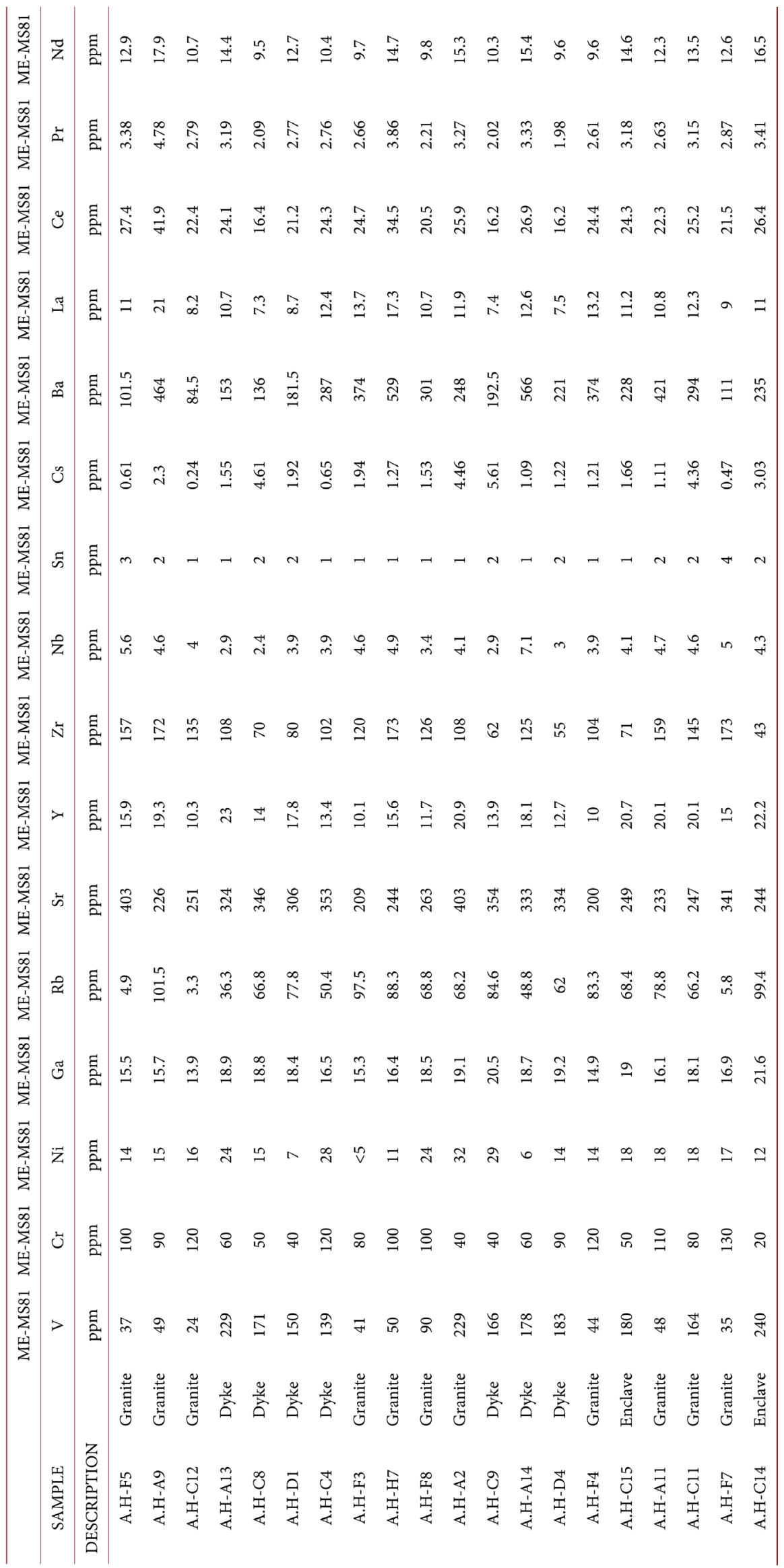




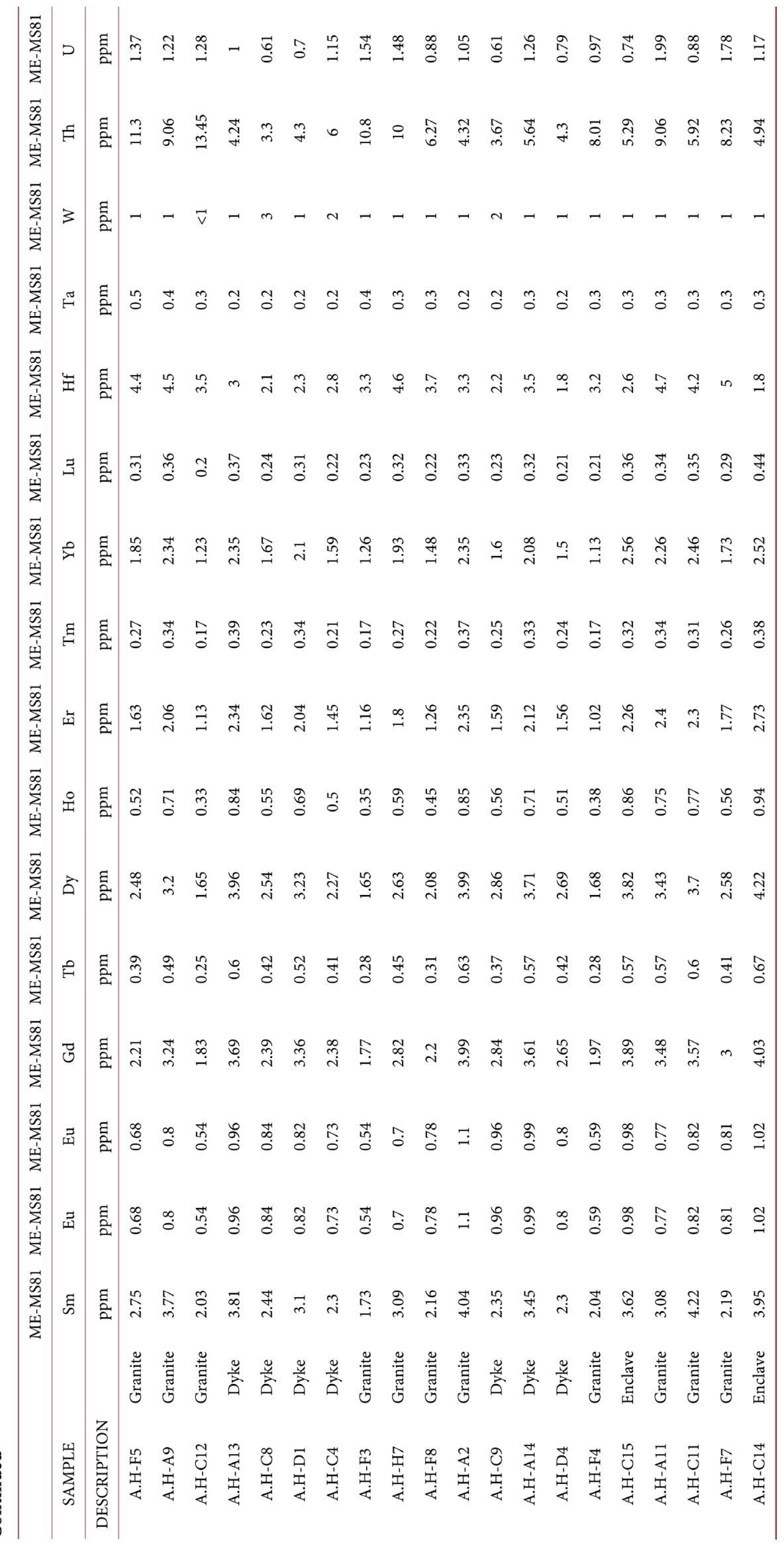



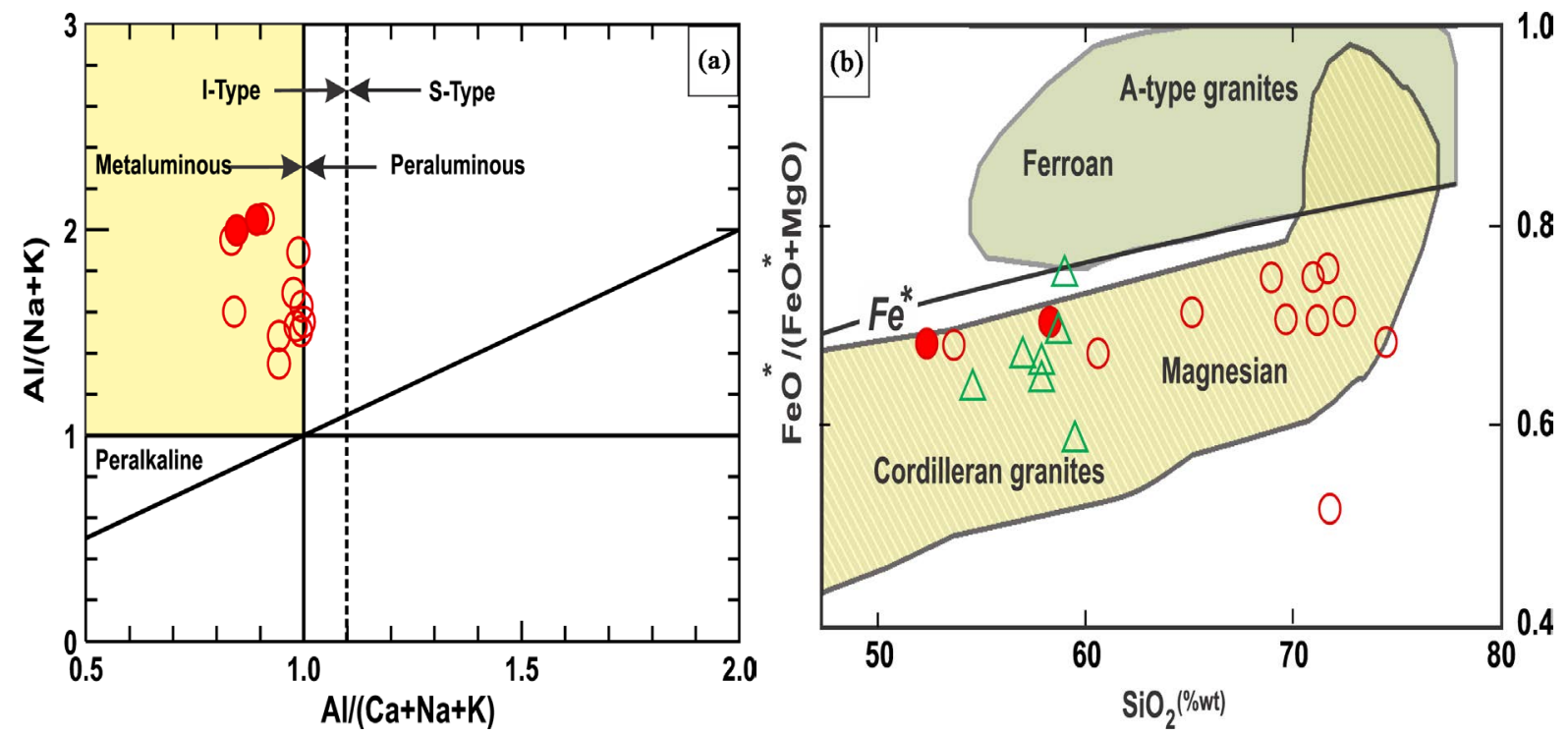

Figure 3. (a) Molar A/CNK $\left[\mathrm{Al}_{2} \mathrm{O}_{3} /\left(\mathrm{K}_{2} \mathrm{O}+\mathrm{Na}_{2} \mathrm{O}+\mathrm{CaO}\right)\right]$ vs. $\mathrm{A} / \mathrm{NK}\left[\mathrm{Al}_{2} \mathrm{O}_{3} /\left(\mathrm{K}_{2} \mathrm{O}+\mathrm{Na}_{2} \mathrm{O}\right)\right]$ diagram, (b) Granitoied type identification by $\mathrm{FeO}^{*} /\left(\mathrm{MgO}+\mathrm{FeO}^{*}\right)$ Vs. $\mathrm{SiO}_{2}$.

obviously that the monzogranites and granodiorites might be related to fractional crystallization procedures (Figure 4).

In the microscopic $\mathrm{Al}_{2} \mathrm{O}_{3} /\left(\mathrm{K}_{2} \mathrm{O}+\mathrm{Na}_{2} \mathrm{O}+\mathrm{CaO}\right)$ vs. $\mathrm{Al}_{2} \mathrm{O}_{3} /\left(\mathrm{K}_{2} \mathrm{O}+\mathrm{Na}_{2} \mathrm{O}\right)$ [A/CNK versus $\mathrm{A} / \mathrm{NK}$ ] figure [11] the quartz-diorites structure, granodiorites, monzogranites scheme to the meta luminous area. The rate of The molecular A/CNK of these rocks are in the range of $[1-1.1]$ of A/CNK (Figure 3(a)), so the stones were of I-kind in the presence of [12], so, these rocks fall in magnesian type of granitoieds and related to cordillerian types of grnitic rocks (Figure $3(\mathrm{~b}))$ [13].

All samples shown low- $\mathrm{K}$ affiliation based on the $\mathrm{K}_{2} \mathrm{O}$ versus $\mathrm{SiO}_{2}$ figure of [14] (Figure 5(a)) and are sub-alkaline relation and relate to the calc-alkaline set from the [15] distribution system (Figure 5(b)).

\section{Tectonic context of emplacement and magma generation}

The Chahar-Gonbad Granitic Complex is normally made of a Medium-K calk-alkaline set (Figure 5(a)) in that quartz-diorite, monzogranite, and granodiorite were the predominant stone models. Area associations, geochemistry, and petrography these stones present community to interventions standard of the dynamic continental boundaries. Various investigations recommend that trace parts could be utilized to distinguish among the various tectonic contexts of granitoid magmas [11] [12] [13]. The Chahar-Gonbad granitoid in the geotectonic distribution of [14] [15] are incorporated as volcanic arc stones (Figures 6(a)-(d)). Moreover, as explained beforehand, granitoid of the Chahar-Gonbad field improved in LILE like $\mathrm{Rb}$ and $\mathrm{Cs}$, concerning the HFSE, particularly $\mathrm{Nb}$ and $\mathrm{Ti}$ (Figure 7). Magmas via these geochemical characteristics are frequently ascribed to the subduction-associated conditions [16]. High $\mathrm{Th} / \mathrm{Yb}$ rates related via special rates for $\mathrm{Th} / \mathrm{Yb}$ are compatible via continental arc magmas (Figure 7). 

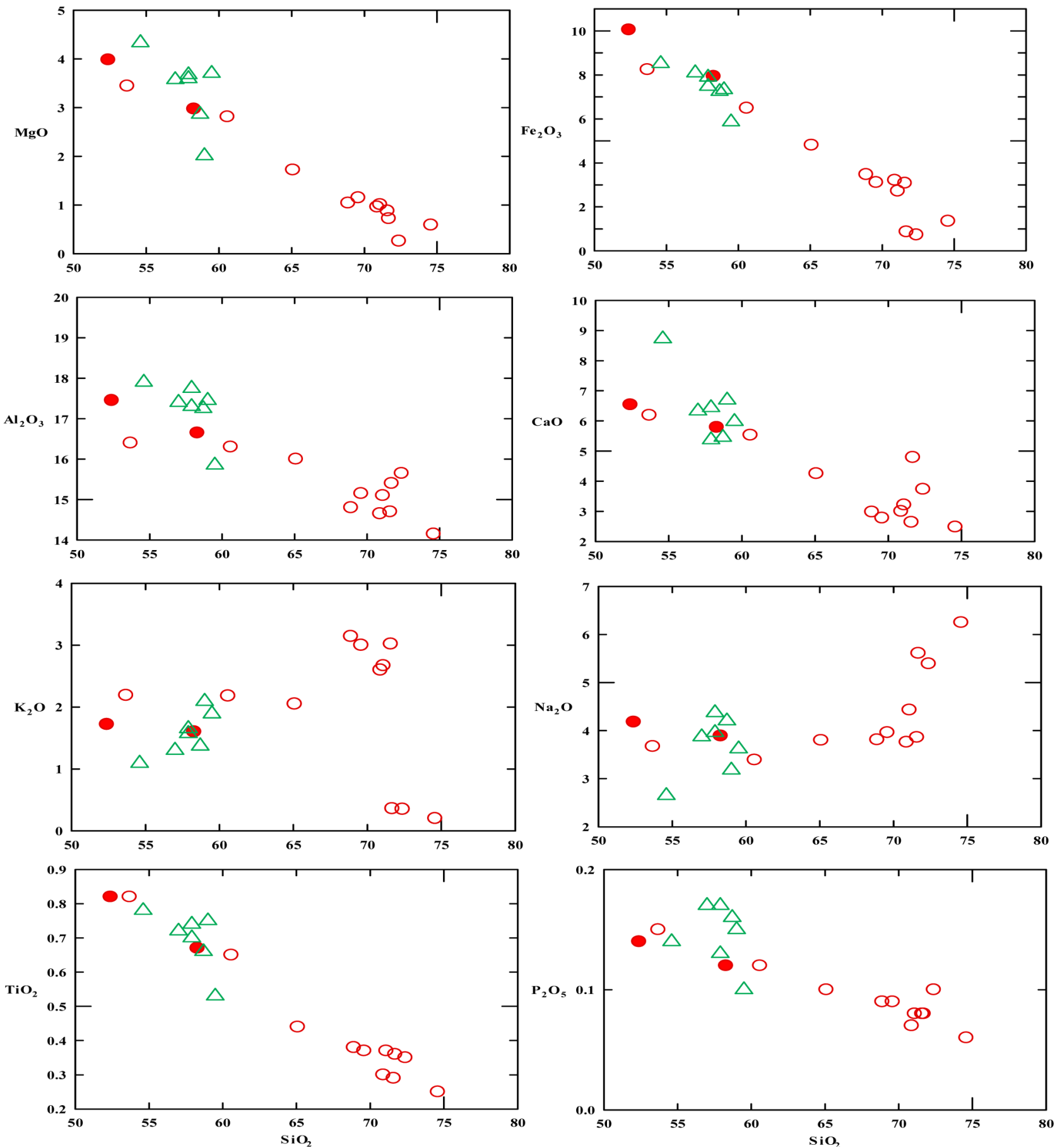

Figure 4. Harker figures for major factors of the Chahar-Gonbad Granitoid complex.

\section{Conclusions}

The Chahar-Gonbad complex can be described as follows according to the evidence:

- A majority of the plutonic rocks are granites and granodiorites.

- Hydrothermal alterations have affected the intrusions.

- The study of the variation of the major elements shows that the samples of the three studied intrusions all formed in a similar setting. 

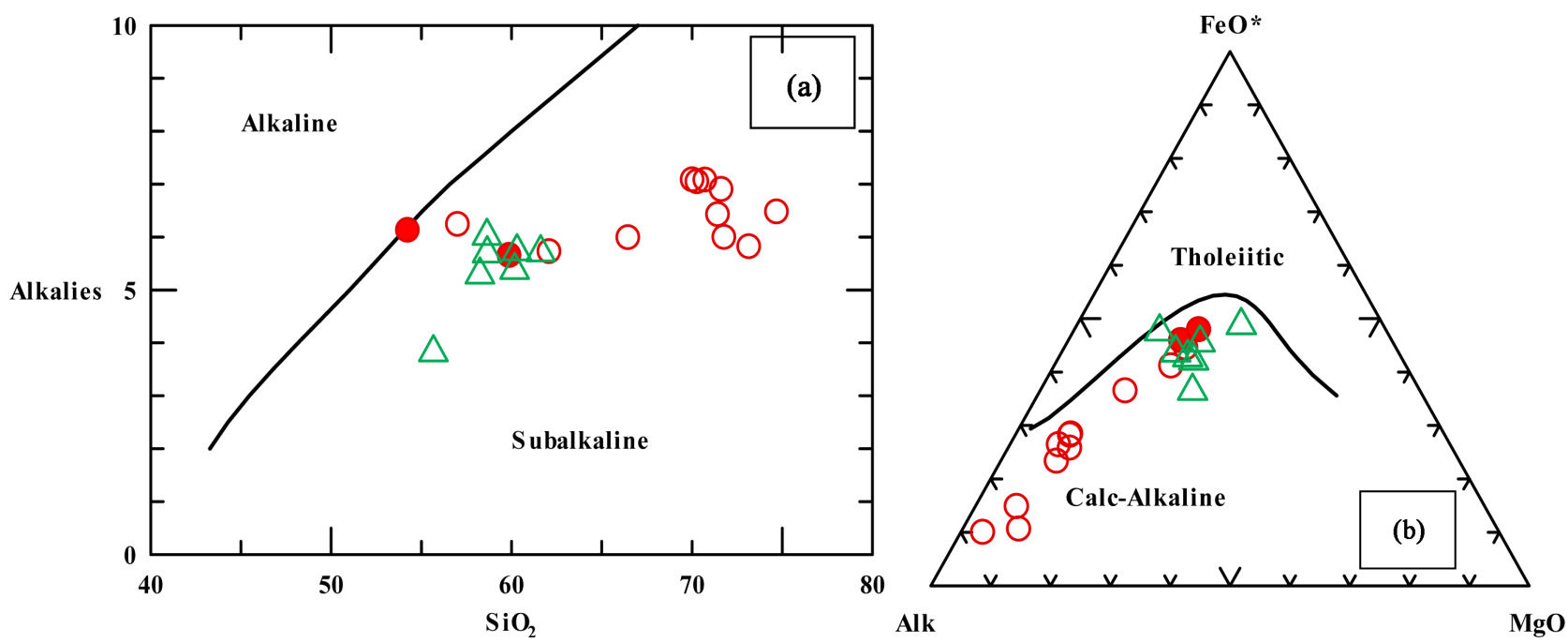

Figure 5. (a) $\mathrm{K}_{2} \mathrm{O}$ Versus. $\mathrm{SiO}_{2}$ plots via area; (b) AFM plot via are delineated after.
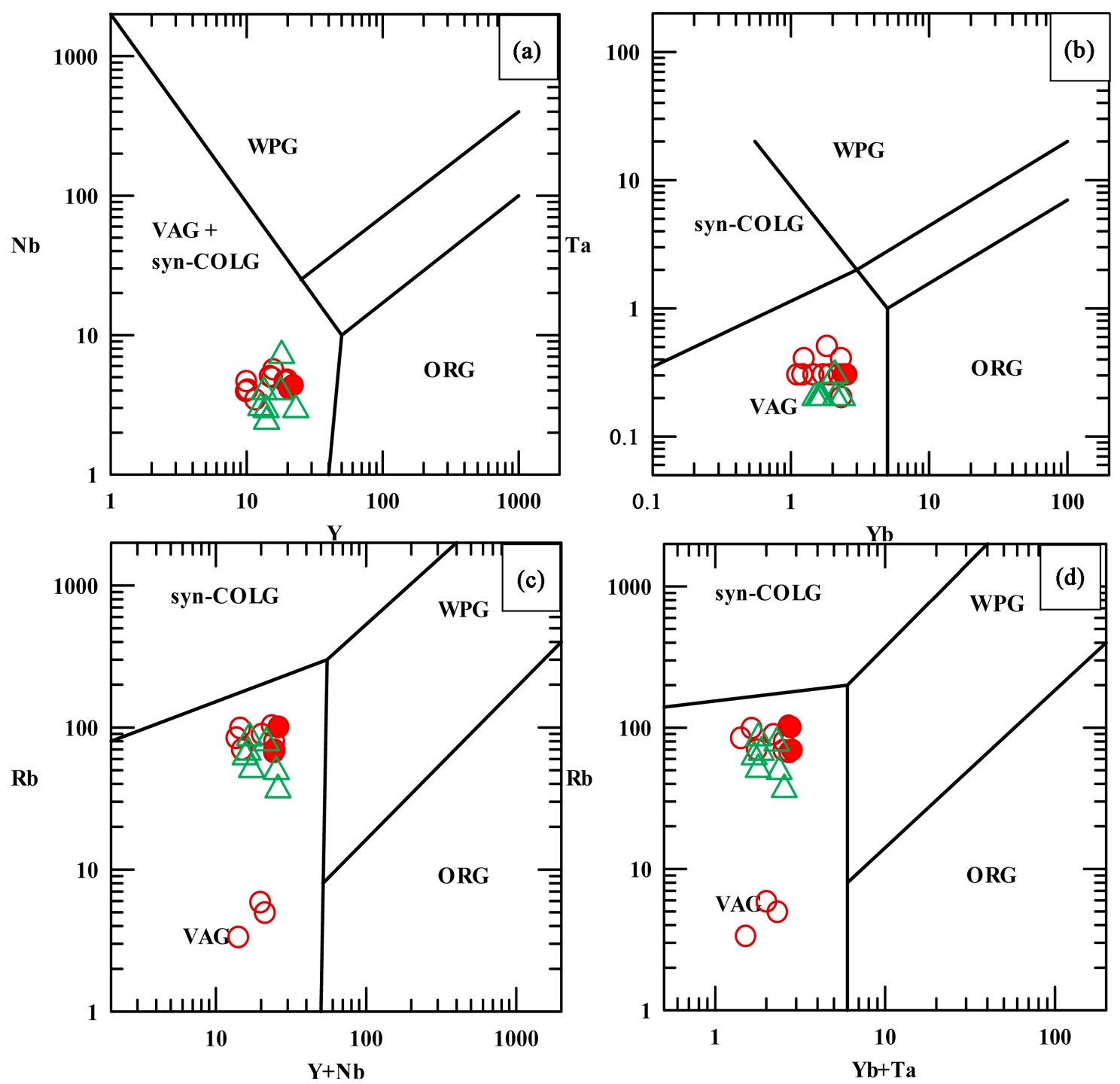

Figure 6. (a)-(d). $\mathrm{Rb}$ vs. $(\mathrm{Yb}+\mathrm{Ta}), \mathrm{Rb}$ versus $(\mathrm{Nb}+\mathrm{Y}), \mathrm{Rb}$ versus $(\mathrm{Ta}+\mathrm{Yb})$, $\mathrm{Ta}$ versus $\mathrm{V}$ and $\mathrm{Ta}$ versus $\mathrm{Yb}$ plots of Pearce (1984). 


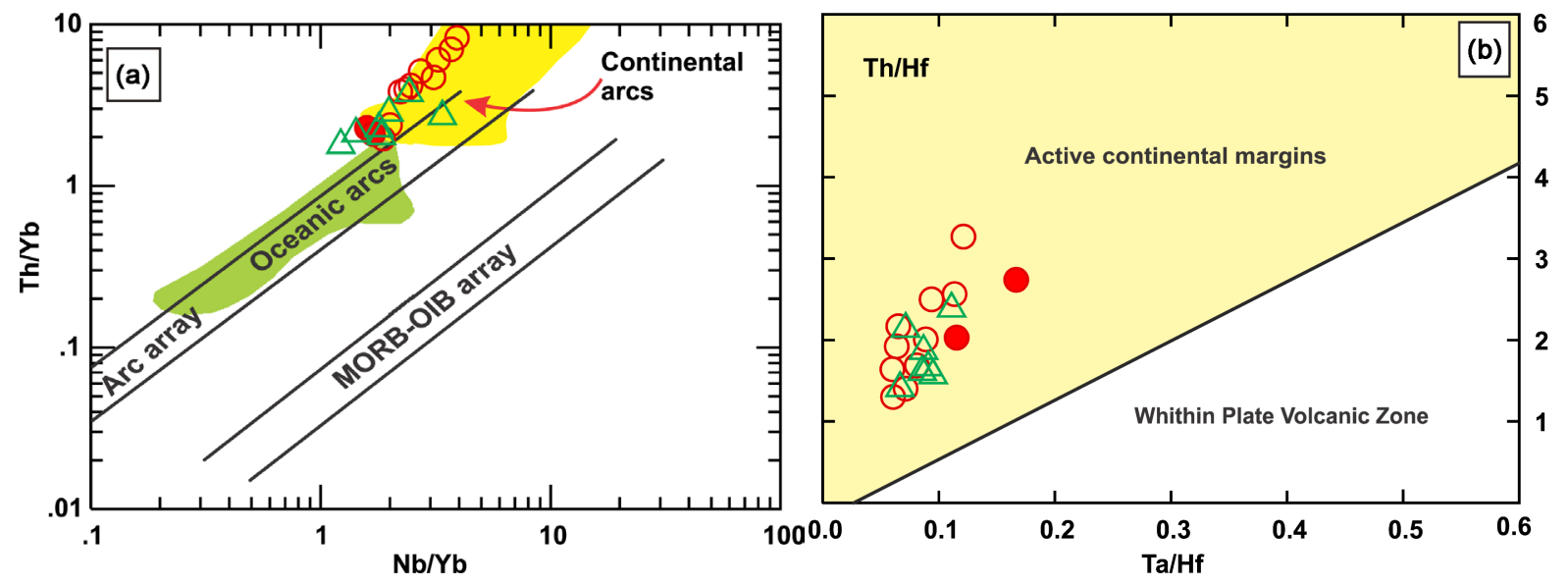

Figure 7. (a) Th/Yb ratios vs. Th/Yb are compatible via continental arc magmas. (b) Ta/Hf ratios vs. Th/Hf Pearce (2008).

- The granitic magmas show typical calc-alkaline trends.

- The intrusions are post orogenic granitoids and shown within plate granite features.

So, the Chahar-Gonbad Granitoid Complex is composed of some factors containing monzogranite, quartz diorite, and granodiorite. The geochemical properties, mineralogy, and petrography of these stones are relative to the standard I-kind stones. The Complex refers to metal luminous, a medium-K calk-sub alkaline range, and presents geochemical features standard of volcanic arc stones compared to an actual continental border. The geochemical records for the Chahar-Gonbad granitoid are a descent from a screen origin, and it can be recommended that the granitoid started by partial melting of mantle protoliths having various structures in a deforming operating border. The obtained results are compatible via the common pattern of [17] that considered that the Sirjan-Sanandaj calc-alkaline magmatic arc made over a high angle subducting oceanic plate in the Neotethyan subduction region.

\section{References}

[1] Caillat, C., Dehlavi, P. and Martel Jantin, B. (1978) Geologie de la region de Saveh (Iran). Contribution a l'etude du volcanism et du plutonismtertiaresde la zone de I Irancentral. These de doctorat de specialities.

[2] Chappell, B.W. and White, A.J.R. (1974) Two Contrasting Granite Types. Pacific Geology, 8, 173-174.

[3] Chappell, B.W. and White, A.J.R. (1992) I and S-Type Granites in the Lachlan Fold Belt. Transactions of the Royal Society of Edinburgh: Earth Sciences, 83, 1-26. https://doi.org/10.1017/S0263593300007720

[4] Alavi, M. (1994) Tectonics of the Zagros Orogenic Belt of Iran: New Data and Interpretations. Tectonophysics, 229, 211-238. https://doi.org/10.1016/0040-1951(94)90030-2

[5] Berberian, M. and King, G.C. (1981) Towards a Palaeogeography and Tectonics Evolution of Iran. Canadian Journal of Earth Sciences, 18, 210-265. https://doi.org/10.1139/e81-019

[6] Berberian, F. and Berberian, M. (1981) Tectono-Plutonic Episodes in Iran. In: Gupta, H.K. and Delany, F.M., Eds., Zagros Hindukosh, Himalaya Geodynamic Evolu- 
tion. American Geophysical Union, Washington DC, 5-32. https://doi.org/10.1029/GD003p0005

[7] Chappell, B.W. (1999) Aluminium Saturation in I- and S-Type Granites and the Characterization of Fractionated Haplogranites. Lithos, 46, 535-551. https://doi.org/10.1016/S0024-4937(98)00086-3

[8] Cotton, J. and Le Dez, A. (1995) Origin of Anomalous Rare Earth Element and Yitrium Enrichment in Subaerially Exposed Basalts: Evidence from France Polynesia. Chemical Geology, 119, 115-138. https://doi.org/10.1016/0009-2541(94)00102-E

[9] Dargahi (2007) Post-Collisional Miocene Magmatism in the Sarcheshmeh-Shahrebabak Region NW of Kerman: Istopic Study, Petrogenetic Analysis and Geodynamic Pattern of Granitoid Intrusive and the Role of Adakitic Magmatism in Development of Copper Mineralization. Unpublished Ph.D. Thesis, Shahid Bahonar of University Kerman, 310 p.

[10] Pearce, J.A. and Harris, N.B.W. (1984) Trace Element Discrimination Diagrams for the Tectonic Interpretation of Granitic Rocks. Journal of Petrology, 25, 956-983. https://doi.org/10.1093/petrology/25.4.956

[11] Pearce, J.A. (1983) Role of the Sub-Continental Lithosphere in Magma Genesis at Active Continental Margins. In: Hawkesworth, C.J. and Norry, M.J., Eds., Continental Basalts and Mantle Xenoliths, Shiva Publishing, Nantwich, 158-185.

[12] Pearce, J.A. (2008) Geochemical Fingerprinting of Oceanic Basalts with Applications to Ophiolite Classification and the Search for Archean Oceanic Crust. Lithos, 100, 14-48. https://doi.org/10.1016/j.lithos.2007.06.016

[13] Shahabpour, J. (2007) Island-Arc Affinity of the Central Iranian Volcanic Belt. Journal of Asian Earth Sciences, 30, 652-665. https://doi.org/10.1016/j.jseaes.2007.02.004

[14] Stocklin, J. (1981) A Brief Report on Geodynamics in Iran. In: Gupta, H.K. and Delany, F.M., Eds., Zagros, Hindu Kush, Himalaya Geodynamic Evolution, American Geophysical Union, Geodynamics Series, Vol. 3, 70-74. https://doi.org/10.1029/GD003p0070

[15] Ronald, F.B., Barnes, C.G., Collins, W.J., Arculus, R.J., Allis, D.J. and Frost, C.D. (2001) A Geochemical Classification for Granitic Rocks. Journal of Petrology, 42, 2033-2048. https://doi.org/10.1093/petrology/42.11.2033

[16] Harris, N.B.W. and Pearce, J.A. (1986) Geochemical Characteristics of CollisionZone Magmatism. In: Coward, M.P. and Ries, A.C., Eds., Collision Tectonics, Geological Society London, Special Publication, 19, 67-81.

https://doi.org/10.1144/GSL.SP.1986.019.01.04

[17] Irvine, T.N. and Baragar, W.R.A. (1971) A Guide to the Chemical Classification of the Common Volcanic Rocks. Canadian Journal of Earth Sciences, 8, 523-548.

https://doi.org/10.1139/e71-055 
Submit or recommend next manuscript to SCIRP and we will provide best service for you:

Accepting pre-submission inquiries through Email, Facebook, LinkedIn, Twitter, etc. A wide selection of journals (inclusive of 9 subjects, more than 200 journals)

Providing 24-hour high-quality service

User-friendly online submission system

Fair and swift peer-review system

Efficient typesetting and proofreading procedure

Display of the result of downloads and visits, as well as the number of cited articles Maximum dissemination of your research work

Submit your manuscript at: http://papersubmission.scirp.org/

Or contact ojg@scirp.org 